\title{
Seed Morpho - Metric, Physiological and Biochemical Characterization on Carrot (Daucus carota L.) Genotypes
}

\author{
Dharini $^{1 *}$, K. Vijay Kumar ${ }^{1}$, N.M. Shakuntala ${ }^{1}$, S.M. Prashant ${ }^{1}$, \\ M.G. Patil ${ }^{2}$ and R.V. Beladhadi ${ }^{3}$ \\ ${ }^{1}$ Department of Seed Science and Technology, University of Agricultural Sciences, \\ Raichur, 584104, Karnataka, India \\ ${ }^{2}$ Department of Horticulture, University of Agricultural Sciences, Raichur, 584104, \\ Karnataka, India \\ ${ }^{3}$ Department of Soil Science and Agricultural Chemistry, University of Agricultural Sciences, \\ Raichur, 584104, Karnataka, India \\ *Corresponding author
}

\section{A B S T R A C T}

Laboratory experiments on seed morpho-metric, physiological and biochemical tests were carried out at Department of Seed Science and Technology, College of Agriculture, University of Agricultural Sciences, Raichur during 2017-18. In the present study 13 accessions were used viz., IC623126, IC-623129, IC-623127, IC-614611, IC-614612, IC-623128, IC-616039, IC-623130, IC591033, IC-405214, IC-565022, IC-512325 (procured from NBPGR, New Delhi) and a Local variety (Belumgi, Kalburgi Dist.) to assess the seed morpho-metric characters viz., seed colour, spines on seed (by using Leica microscope), seed length, seed breadth, length/breadth ratio (by using Biovis

\section{Keywords}

Carrot, Seed morpho-metric, Physiological tests, Biochemical tests

Article Info

Accepted:

22 January 2019

Available Online:

10 February 2019 image analyzer), test weight; physiological tests viz., germination, root length, shoot length, seedling length, seedling dry weight, seedling vigour index I and II, biochemical tests viz., dehydrogenase enzyme activity and alpha amylase activity, using Complete Randomized Design in four replication. The results revealed that, the genotypes showed varied response to biochemical tests, physiological parameters and seed morpho-metric characters. Out of 13 genotypes, in 2 genotypes the seed colour was pale brown and in 11 genotypes the seed colour was field drab colour. Spines were present on 9 genotypes and absent in 3 genotypes. The seed length was highest $(7.37 \mathrm{~mm})$ in IC-405214 and lowest $(5.05 \mathrm{~mm})$ in IC-616039. The seed breadth was seen highest $(4.95 \mathrm{~mm})$ in IC-623126 and lowest $(3.62 \mathrm{~mm})$ in IC-565022. In IC-512325 the length/breadth ratio was highest $(1.81 \mathrm{~mm})$, where as in IC-623126 length/breadth ratio was lowest $(1.16 \mathrm{~mm})$. It was observed that, the test weight of IC-512325 was highest $(4.28 \mathrm{~g})$ and lowest $(1.10 \mathrm{~g})$ in IC-623129. Local variety recorded high germination percentage $(83.00 \%)$, better seedling length IC-623130 $(17.78 \mathrm{~cm})$, higher seedling dry matter $(27.60 \mathrm{mg})$ in Local variety with maximum SVI-I (1302.17) and SVI-II (229.47). The genotype IC-623126 recorded comparatively lower germination percentage (43.00\%), numerically lesser seedling length $(9.58 \mathrm{~cm})$ in IC-623128, minimum seedling dry matter $(1.15 \mathrm{mg})$ in IC-614612 with low SVI-I (436.52) in IC-512325 and low SVI-II (54.58) in IC-623126. The highest dehydrogenase enzyme activity was observed in in Local variety (0.576) and lowest in IC-623127 (0.080), with the mean of 0.239 . The highest $\alpha$-amylase activity was recorded in Local variety (18.82 $\mathrm{mm}$ ) and lowest in IC-623128 (14.05 $\mathrm{mm})$ with mean $16.15 \mathrm{~mm}$. It can be concluded that, among the genotypes studied there exists diversity. The characters studied can be used effectively in formulation of National DUS guidelines in India. 


\section{Introduction}

Carrot (Daucus carota L.) is one of the most important root vegetable crops. It is a biennial plant having diploid $(2 \mathrm{n}=2 \mathrm{x}=18)$ chromosome number. It is one of ten economic vegetables in the world. It belongs to Umbelliferae family and is the most widely used member of this family. This family contains about 250 genera and includes about 2,500 species such as dill, caraway, cumin, chervil, coriander, fennel, anise, parsley, parsnip, and celery. Daucus is the largest genus of this family so that, according to the recent estimation this genus has more than 25 species (Simon et al., 2008). Carrot is native to Asia, Europe, North of Africa and the Mediterranean region and for the first time, the Greeks used it as a drug (Simon, 2008) and cultivation of carrots possibly has started since the tenth century in Iran, Afghanistan and Iraq. Carrot with carotenoids such as, $\beta$ carotene and alpha-carotene, is considered as a rich source of antioxidants. Root of this vegetable has been seen in different colors such as yellow, white, purple, red and orange that the carotenoid content of each carrot depends on its root color (Baranski et al., 2011) and white carrot lack pigment (Rubatzky et al., 1997).

Commercially cultivated carrots depend on seed for regeneration. As seed is the most important basic input, it should be of good quality and the most vital attributes of that quality is its germination and emergence potential under field conditions. Cultivation of carrot is carried out in cooler regions as it requires $15-20^{\circ} \mathrm{C}$ temperature for flowering and seed production. Seed germination and subsequent seedling growth define crucial steps for entry into the plant life cycle and proper seed germination is a basic prerequisite for getting a better crop yield. An important problem encountered in the cultivation of carrot is the poor germination of the seeds when planting is done in extremely warm temperatures. High temperature may delay or inhibit seed germination in the field, reduce uniformity, total establishment and ultimately reduce the yield in carrot. Poor germination of seeds is of common occurrence in the family Umbelliferae and rudimentary embryos have also been found in members of this family. It has been suggested that the seeds with rudimentary embryos are the cause for the delayed germination often encountered in carrots. Also the smaller size of carrot seeds causes difficulty in field emergence (Robinson, 1954).

Characterization of cultivars is crucial to the varietal purity and maintenance. The ability to distinguish and clearly identify varieties of cultivated species is fundamental for the seed trade. In any crop improvement programme, information on genetic divergence is an important factor for obtaining high yielding variety (Rhman and Munsur, 2009). When initiating a breeding programme, it is important to gather information on the traits of agronomic importance. Success in hybridization and subsequent selection of desirable segregants depends largely on the selection of parents with high genetic variability for different characters (Sabesan et al., 2009). Knowledge on genetic divergence is therefore, fundamental to identify and organize the available genetic resources aiming at the production of promising cultivars (Palomino et al., 2005). The characterization of individuals, accessions and cultivars is useful in identifying the duplicate accessions and cultivars in germplasm collection and for the choice of the parental genotypes in breeding programme (Davila et al., 1998).

Information on seed morpho-metric, physiological and biochemical characterization on carrot genotypes is very scanty. Therefore, the present study was 
undertaken to investigate the characterization of genotypes based on seed morpho-metric, physiological and biochemical tests.

\section{Materials and Methods}

IC-623126, IC-623129, IC-623127, IC614611, IC-614612, IC-623128, IC-616039, IC-623130, IC-591033, IC-405214, IC565022, IC-512325 (procured from NBPGR, New Delhi) and a Local variety (Belumgi, Kalaburgi Dist.) were used in this study and were maintained at Department of Seed Science and Technology, College of Agriculture, University of Agricultural Sciences, Raichur, 584104. A range of seed traits were measured using the procedures described below.

\section{Morpho-metric characters}

Seed morpho-metric characters viz., length $(\mathrm{mm})$, breadth $(\mathrm{mm})$, length to breadth ratio was measured by taking ten seeds with ten replicaions usind Biovis image analyser, seed colour, spines on seed by using Leica microscope. And thousand seed weight was recorded by taking thousand seeds randomly, which was expressed in grams.

\section{Physiological characters}

Physiological characters viz., germination percentage, shoot length, root length, seedling length, seedling dry weight, seedling vigour index I and II were recorded. The seed germination test was conducted as per the ISTA rules (Anon., 2013) using sixteen replicates of 25 seeds each in the petri plates where seeds were placed on top of two layers of blotter papers and incubated in the walk in germination room which was maintained at 25 $\pm 1^{\circ} \mathrm{C}$ temperature and $90 \pm 2$ per cent $\mathrm{RH}$. At the end of $14^{\text {th }}$ day of the test, the number of normal seedlings in each replication was counted and the germination was calculated and expressed in percentage. From the germination test, ten normal seedlings were randomly selected from each treatment of each replication on the $14^{\text {th }}$ day. The shoot length was measured from the tip of shoot to hypocotyl point and the mean length was calculated and expressed in centimeters and the root length was measured from the tip of the root to hypocotyl point and the mean length was calculated and expressed in centimeters (Anon., 2015). From the germination test, ten normal seedlings were selected randomly from each treatment of each replication on $14^{\text {th }}$ day. The seedling length was measured from tip of shoot to root tip and the mean length was calculated and expressed as seedling length in centimetres (Anon., 2015). The randomly selected 10 seedlings for measuring seedling length obtained after final count were dried at $70 \pm 1{ }^{\circ} \mathrm{C}$ for $24 \mathrm{hrs}$ in hot air oven and dry weight in milligram was determined by weighing them in an electronic balance. The seedling vigour index I and II was determined by using the following formula given by (Abdul-Baki and Anderson, 1972).

Seedling Vigour Index $\mathrm{I}=$ Germination percentage $x$ Seedling length $(\mathrm{cm})$

Seedling Vigour Index II = Germination percentage $\mathrm{x}$ seedling dry weight $(\mathrm{mg})$

\section{Biochemical tests}

Biochemical tests viz., dehydrogenase enzyme activity (OD Value), alpha amylase activity (mm).

\section{Dehydrogenase enzyme activity (OD Value)}

Ten seeds from each treatment were taken and preconditioned by soaking in water for overnight at room temperature. The seeds were pierced using a needle. The prepared seeds were soaked in 1 per cent aqueous 
solution of 2, 3, 5-triphenyl tetrazolium chloride solution and placed at $37^{\circ} \mathrm{C}$ in a oven. The stained seeds were thoroughly washed with water and then soaked in $5 \mathrm{ml}$ of 2 methoxy ethanol (methyl cellulose) and kept overnight at room temperature (dark) for extracting the red colour formazan. The intensity of red colour was measured using ELICO UV-VI Spectrophotometer using blue filter $(470 \mathrm{~nm})$ and methyl cellulose as the blank. The OD value obtained was reported as dehydrogenase activity (Shenoy et al., 1990).

\section{Alpha-amylase activity (mm)}

The $\alpha$-amylase activity was analyzed as per the method suggested by Simpson and Naylor (1962). Two gram of agar shreds and one gram of potato starch was mixed together in water to form paste and the volume was made up to $100 \mathrm{ml}$ with distilled water. The homogenous solution of agar-starch mixture after boiling was poured into sterilized petridishes and allowed to settle in the form of gel after cooling. The pre-soaked (for 8 hours) and half cut seeds (with their half endosperm and embryo portion intact) were placed in the petri-dishes in such a way that the endospermic part remained in contact with agar-starch gel. The petri-dishes were closed and kept in dark at $30^{\circ} \mathrm{C}$. After 36 hours the Petri-dishes were uniformly smeared with potassium iodide solution ( $0.44 \mathrm{~g}$ of iodine crystal $+20.008 \mathrm{~g}$ potassium iodide in $500 \mathrm{ml}$ distilled water) and excess solution was drained off after few minutes. The diameter of halo (clear) zone formed around the seed was measured in $\mathrm{mm}$ and reported as $\alpha$-amylase activity.

\section{Results and Discussion}

In the present study, On the basis of variation in seed morpho-metric characters assessed through Biovis image analyser and Leica microscope genotypes were characterized
(Table 1). The genotype IC-405214 was having $7.37 \mathrm{~mm}$ seed length, $4.51 \mathrm{~mm}$ seed width, 1.56 length / width ratio with $3.25 \mathrm{~g}$ 1000- seeds weight and IC-616039 was having numerically less seed length of $5.05 \mathrm{~mm}$, seed width of $3.66 \mathrm{~mm}$, very low 1.1 .33 length / width ratio with $1.50 \mathrm{~g}$ of 1000 -seeds weight. Based on the seed length and seed width, the genotypes were characterized. This characterization was based on the classification of linseed varieties earlier by Negash et al., (2015).

As none of the seed can be treated as ideal due to influence of environment, they could not help in identification of individual genotypes based on only seed morphological characteristics, which should be supported by either, biochemical tests or morphological characterization. The average of variation within character between the objects of optimum sample size can be taken as a reliable character descriptor (Keefe and Draper, 1990). In the present study 2 carrot genotypes seed colour was pale brown and remaining 11 were field drab (42.4\% red, $32.9 \%$ green and $11.8 \%$ blue) colour. The spines was present in 10 genotypes and and absent in 3 genotypes.

The Local variety recorded good germination percentage $(83.00 \%)$, better seedling length IC-623130 $(17.78 \mathrm{~cm})$, higher seedling dry matter $(27.60 \mathrm{mg})$ in Local variety with maximum SVI-I (1302.17) and SVI-II (229.47). The genotype IC-623126 recorded comparatively lower germination percentage (43.00\%), numerically lesser seedling length $(9.58 \mathrm{~cm})$ in IC-623128, minimum seedling dry matter $(1.15 \mathrm{mg})$ in IC-614612 with low SVI-I (436.52) in IC-512325 and low SVI-II (54.58) in IC-623126 (Table 2). Similar results were observed by Venkat Reddy (1991) in soybean, Manjunath Reddy (2005) in cotton. The genotypes carry the desirable traits regarding physiological characters (Negash et al., 2015). 
Table.1 Characterization of genotypes based on seed morpho-metric characters

\begin{tabular}{|c|c|c|c|c|c|c|}
\hline Genotypes & $\begin{array}{l}\text { Seed } \\
\text { length } \\
(\mathrm{mm})\end{array}$ & $\begin{array}{l}\text { Seed width } \\
\quad(\mathrm{mm})\end{array}$ & $\begin{array}{l}\text { Seed length / } \\
\text { width ratio }\end{array}$ & $\begin{array}{l}1000 \text { Seed } \\
\text { weight }(\mathrm{g})\end{array}$ & Seed colour & $\begin{array}{l}\text { Spines on } \\
\text { seed }\end{array}$ \\
\hline IC-623126 & 5.95 & 4.96 & 1.16 & 1.45 & Field drab & Present \\
\hline IC-623129 & 6.15 & 3.85 & 1.57 & 1.10 & Pale brown & Present \\
\hline IC-623127 & 5.27 & 4.39 & 1.21 & 1.63 & Field drab & Present \\
\hline IC-614611 & 6.46 & 4.68 & 1.35 & 2.60 & Field drab & Present \\
\hline IC-614612 & 7.02 & 4.67 & 1.50 & 1.58 & Field drab & Present \\
\hline IC-623128 & 6.09 & 4.17 & 1.44 & 1.85 & Field drab & Present \\
\hline IC-616039 & 5.05 & 3.66 & 1.33 & 1.50 & Field drab & Present \\
\hline IC-623130 & 5.45 & 3.71 & 1.50 & 1.68 & Field drab & Present \\
\hline IC-591033 & 6.07 & 4.35 & 1.41 & 1.88 & Pale brown & Absent \\
\hline IC-405214 & 7.37 & 4.51 & 1.56 & 3.25 & Field drab & Absent \\
\hline IC-565022 & 5.26 & 3.62 & 1.38 & 1.65 & Field drab & Present \\
\hline IC-512325 & 7.22 & 4.03 & 1.81 & 4.28 & Field drab & Absent \\
\hline $\begin{array}{l}\text { Local } \\
\text { variety }\end{array}$ & 6.99 & 4.01 & 1.73 & 4.18 & Field drab & Present \\
\hline Mean & 6.18 & 4.20 & 1.46 & 2.26 & - & - \\
\hline SEm \pm & 0.09 & 0.06 & 0.04 & 0.10 & - & - \\
\hline $\mathrm{CD}$ at $1 \%$ & 0.34 & 0.23 & 0.15 & 0.39 & - & - \\
\hline
\end{tabular}

Table.2a Characterization of genotypes based on physiological tests

\begin{tabular}{|c|c|c|c|c|}
\hline Genotypes & Germination (\%) & $\begin{array}{l}\text { Shoot length } \\
(\mathrm{cm})\end{array}$ & Root length (cm) & $\begin{array}{l}\text { Seedling length } \\
(\mathrm{cm})\end{array}$ \\
\hline IC-623126 & $43(40.98)$ & 4.40 & 6.43 & 11.18 \\
\hline IC-623129 & $63(52.54)$ & 7.40 & 4.43 & 12.18 \\
\hline IC-623127 & $67(54.94)$ & 6.20 & 7.23 & 13.78 \\
\hline IC-614611 & $59(50.18)$ & 7.70 & 5.23 & 13.28 \\
\hline IC-614612 & $59(50.18)$ & 9.30 & 7.13 & 16.78 \\
\hline IC-623128 & $55(47.87)$ & 5.10 & 4.13 & 9.58 \\
\hline IC-616039 & $51(45.57)$ & 8.10 & 3.73 & 12.18 \\
\hline IC-623130 & $47(43.28)$ & 10.10 & 7.33 & 17.78 \\
\hline IC-591033 & $59(50.18)$ & 8.30 & 4.93 & 13.58 \\
\hline IC-405214 & $52(46.15)$ & 7.10 & 3.03 & 10.48 \\
\hline IC-565022 & $55(47.87)$ & 7.40 & 5.73 & 13.18 \\
\hline IC-512325 & $45(42.13)$ & 7.40 & 3.93 & 9.68 \\
\hline Local variety & $83(65.65)$ & 6.90 & 8.43 & 15.68 \\
\hline Mean & $56.76(48.45)$ & 7.34 & 5.51 & 13.02 \\
\hline $\mathrm{SEm} \pm$ & 1.29 & 0.17 & 0.11 & 0.18 \\
\hline $\mathrm{CD}$ at $1 \%$ & 4.94 & 0.64 & 0.42 & 0.67 \\
\hline
\end{tabular}


Table.2b Characterization of genotypes based on physiological tests

\begin{tabular}{|c|c|c|c|}
\hline Genotypes & $\begin{array}{c}\text { Seedling dry } \\
\text { weight }(\mathrm{mg})\end{array}$ & $\begin{array}{c}\text { Seedling vigour } \\
\text { index I }\end{array}$ & $\begin{array}{c}\text { Seedling vigour } \\
\text { index II }\end{array}$ \\
\hline IC-623126 & 1.25 & 481.67 & 54.58 \\
\hline IC-623129 & 1.25 & 768.17 & 79.67 \\
\hline IC-623127 & 1.56 & 924.07 & 104.82 \\
\hline IC-614611 & 1.25 & 784.37 & 74.65 \\
\hline IC-614612 & 1.15 & 990.87 & 68.74 \\
\hline IC-623128 & 1.45 & 527.77 & 80.65 \\
\hline IC-616039 & 1.25 & 622.07 & 64.61 \\
\hline IC-623130 & 1.66 & 836.57 & 78.43 \\
\hline IC-591033 & 1.76 & 802.07 & 104.20 \\
\hline IC-405214 & 1.76 & 545.85 & 91.91 \\
\hline IC-565022 & 1.76 & 725.77 & 97.18 \\
\hline IC-512325 & 2.16 & 436.52 & 97.66 \\
\hline Local variety & 2.76 & 1302.17 & 229.47 \\
\hline Mean & $\mathbf{1 . 6 2}$ & $\mathbf{7 4 9 . 8 4}$ & $\mathbf{9 4 . 3 5}$ \\
\hline SEm \pm & $\mathbf{0 . 0 7}$ & $\mathbf{0 . 5 1}$ & $\mathbf{0 . 4 4}$ \\
\hline CD at $1 \%$ & $\mathbf{0 . 2 5}$ & $\mathbf{2 . 0 0}$ & $\mathbf{1 . 7 5}$ \\
\hline
\end{tabular}

Table.3 Characterization of genotypes based on biochemical tests

\begin{tabular}{|c|c|c|}
\hline Genotypes & $\begin{array}{c}\text { Dehydrogenase activity } \\
\text { (OD values at 470 } \mathrm{nm})\end{array}$ & $\begin{array}{c}\alpha \text {-amylase activity } \\
(\mathrm{mm})\end{array}$ \\
\hline IC-623126 & 0.172 & 16.62 \\
\hline IC-623129 & 0.161 & 15.83 \\
\hline IC-623127 & 0.080 & 15.13 \\
\hline IC-614611 & 0.105 & 16.06 \\
\hline IC-614612 & 0.138 & 17.20 \\
\hline IC-623128 & 0.148 & 14.05 \\
\hline IC-616039 & 0.126 & 17.17 \\
\hline IC-623130 & 0.253 & 18.24 \\
\hline IC-591033 & 0.392 & 15.80 \\
\hline IC-405214 & 0.289 & 14.74 \\
\hline IC-565022 & 0.304 & 15.38 \\
\hline IC-512325 & 0.365 & 14.90 \\
\hline Local variety & 0.576 & 18.82 \\
\hline Mean & $\mathbf{0 . 2 3 9}$ & $\mathbf{1 6 . 1 5}$ \\
\hline SEm \pm & $\mathbf{0 . 0 1 3}$ & $\mathbf{0 . 1 4}$ \\
\hline CD at $1 \%$ & $\mathbf{0 . 0 4 8}$ & $\mathbf{0 . 5 2}$ \\
\hline
\end{tabular}


Significant variations were observed among the genotypes with respect to dehydrogenase enzyme activity. The highest dehydrogenase enzyme activity was observed in in Local variety (0.576) and lowest in IC-623127 (0.080), with the mean of 0.239 (Table 3). Dehydrogenase enzyme which exists in mitochondria and necessary for respiratory process indicate the level of seed viability and vigour (Anon., 2012).

The $\alpha$-amylase activity also varied significantly among the genotypes. The highest $\alpha$-amylase activity was recorded in Local variety $(18.82 \mathrm{~mm})$ and lowest in IC$623128(14.05 \mathrm{~mm})$ with mean $16.15 \mathrm{~mm}$ (Table 3). The variations might be due to genetic makeup of the genotypes.

It can be concluded that, among the genotypes studied there exists diversity. These characters can be used effectively in formulation of National DUS guidelines in India by PPV\&FR Authority.

The seed morphological parameters characterized through Biovis seed image analyser and Leica microscope can be effectively used in assessment of genotypes, which is efficient, quick and non-destructive.

\section{References}

Abdul-Baki, A. A. and Anderson, J. D., 1973, Vigour determination in soybean by multiple criteria. Crop Sci., 13: 630633.

Anonymous, 2012, agricoop.statistics.com.

Anonymous, 2013, ISTA, International rules for seed testing, Seed. Sci. Technol., 27: $25-30$.

Anonymous, 2015, http://agricoop.nic.in/agristatistics.htlm.

Baranski, R., Kaminska, I., Schulz-Witte, J., Nothnagel, T. and Carle, R., 2010, Characterisation of carrots of various root colour. Ecological chemistry and engineering, 7(9): 1053-1058.

Davila, J. A., Sanchez, M. P., Loarce, Y. and Ferrer, E., 1998, The use of random amplified microsatellite polymorphic DNA and coefficients of parentage to determine genetic relationship in barley. Genome. 41. 477- 486. Daynard

Keefe, P. D. and Draper, S. R., 1990, The measurement of new characters for cultivar identification in wheat using machine vision. Seed Sci. and Technol., 14: 715-724.

Manjunath Reddy, C. A., 2005, Varietal characterization by morphological, chemical and electrophoresis of cotton (Gossypium spp.) hybrids and their parents. M. Sc. (Agri) Thesis, Univ. Agric. Sci., Dharwad, (India).

Negash, W., Heslop-Harrison, J. S. and Adugna, W., 2015, Diversity in 198 Ethiopian linseed (Linum usitatissimum) accessions based on morphological characterization and fibre characteristics. Genet Resour Crop Evol, DOI 10.1007/s10722-014-0207-1. New Delhi, pp. 122-143.

Palomino, E. C., Mori, E. S., Zimback, L., Tambarussi, E. V. and Moracs, C. B., 2005, Genetic diversity of common bean genotypes of carioca commercial group using RADP markers. Crop Breed. And Appl. Biotech., 5: 80-85.

Rhman, M. M and Munsur, A. Z. A., 2009, Genetic divergence analysis of lime. $J$. Bangla. Agril. Uni., 7(1): 33-37.

Robinson, R. W., 1954, Seed germination problems in the Umbelliferae. The Bot. Rev., 20(9): 531-550.

Rubatzky, V. E. and Yamaguchi, M., 1997, World vegetables, principal, production and nutritive values. champan and hall, Inter. Thompson Publishing, New York.

Shenoy, S. S. and Joshi, R. P., 1990, Studies on invigouration on vegetables seeds of tomato (Lycopersicum esculentum) and 
cauliflower (Brassica oleracea). Simpson, G. M. and Naylar, J. M., 1962, Progressive Hortic., 17(3): 267-269.

Simon, P. W., 2008, Carotenoid biosynthesis structural genes in carrot (Daucus carota) isolation, sequence characterization, single nucleotide polymorphism (SNP) markers and genome mapping. Theor. Appl. Genet., 114: 693-704. Dormancy studies in seeds of Avena fatuva and relationship between maltase, amylases and gibberellins. Can. J. Bot., 40: 19591673.

Venkat, R. D. M., 1991, Investigations on seed technology of soybean, Ph. D. Thesis, Univ. Agric. Sci., Bangalore (India).

\section{How to cite this article:}

Dharini, K. Vijay Kumar, N.M. Shakuntala, S.M. Prashant, M.G. Patil and Beladhadi, R.V. 2019. Seed Morpho - Metric, Physiological and Biochemical Characterization on Carrot (Daucus carota L.) Genotypes. Int.J.Curr.Microbiol.App.Sci. 8(02): 3333-3340. doi: https://doi.org/10.20546/ijcmas.2019.802.388 